TITLE:

\title{
STUDIES ON THE TALITRIDAE (AMPHIPODA, CRUSTACEA) IN JAPAN -I. TAXONOMY OF TALORCHESTIA AND ORCHESTOIDEA-
}

\author{
$\operatorname{AUTHOR(S):~}$
}

Morino, Hiroshi

\section{CITATION:}

Morino, Hiroshi. STUDIES ON THE TALITRIDAE (AMPHIPODA, CRUSTACEA) IN JAPAN -I. TAXONOMY OF TALORCHESTIA AND ORCHESTOIDEA-. PUBLICATIONS OF THE SETO MARINE BIOLOGICAL LABORATORY 1972, 21(1): 43-65

ISSUE DATE:

1972-12-01

URL:

http://hdl.handle.net/2433/175797

RIGHT: 


\title{
STUDIES ON THE TALITRIDAE (AMPHIPODA, CRUSTACEA) IN JAPAN \\ I. TAXONOMY OF TALORCHESTIA AND ORCHESTOIDEA ${ }^{1)}$
}

\author{
HIROSHI MORINO
}

Seto Marine Biological Laboratory

With Text-figures 1-12

With regard to the taxonomy of Japanese Talitridae, Iwasa (1939) made the first revisional study, although the paper of the Russian scientist Derzhavin (1937) who treated the Talitridae collected from Russian shores of the Japan Sea was unfortunately inaccessible to him at that time. In 1944, the Danish scientist Stephensen reported the Japanese amphipods including Talitridae in the material sent by a Japanese scientist for determination, and he identified the family mainly after Iwasa with some remarks on the differences from his descriptions. After Derzhavin, Gurjanova (1951) made an extensive work on Amphipoda in Russia, particularly in the Far-Eastern seas, and Bulycheva (1957) published an intensive study on the classification of the Talitroidea, in which Japanese species were also referred to and some corrections were made as to Iwasa's work.

Recently I made extensive collecting trips, aiming at the taxonomical and ecological as well as distributional surveys of talitrids in Japan. As a result of this field study, I obtained several species which were new to Japan and on closer examination some of them were revealed to be new to science. At the same time, I collected the data on them from the ecological viewpoint, which might throw light upon the problems inherent to the classification of this group. Indeed, in order to comprehend the nature of the talitrids, as in the case of any group of animals, the studies not only from the taxonomical viewpoint, but also on other biological aspects, for example, the study on the life history as an ecological approach, must contribute much.

The present paper deals with two species of Talorchestia and one species of Orchestoidea, which were found in the material collected:

1) Talorchestia sinensis Chilton, new to Japan,

2) Talorchestia nipponensis n. sp., and

3) Orchestoidea trinitatis Derzhavin.

The members of Orchestia will be reported in a succeeding paper.

1) Contributions from the Seto Marine Biological Laboratory, No. 567.

Publ. Seto Mar. Biol. Lab., XXI (1), 43-65, $1972 . \quad$ (Article 5) 
I would like to express my sincere gratitude to Professor H. Utinomi for leading me to the present study. I wish to thank Dr. T. Tokioka and Dr. S. Nishimura for critical reading of the manuscript. Dr. S.M. Shiino put his literature at my disposal, to whom I am very grateful. My thanks are also due to Mr. H. Tanase of the Laboratory, Mr. H. Inoue of Hachigo Senior High School, Dr. T. Ito of Hokkaido University and Dr. E. Harada of Kyoto University, for affording me specimens, of whom the last also gave me helpful advice.

\section{Family Talitridae Stebbing, Emend. Bulycheva}

Bulycheva (1957) partitioned the Talitridae and restricted the genera of the family as follows; Talitrus, Talorchestia, Orchestoidea and Orchestia. So far in Japan, Talitrus has not been known.

It has long been known that the Talitridae is a difficult group to classify at the specific as well as the generic level. They show drastic sexual dimorphism and their distinct specific identification depends upon fully matured males, since the diagnoses of the species are represented by dimorphic characters of male specimens in almost all taxonomical papers.

Determination of the genus, on the other hand, has been done by the character of the females, which is not so clear-cut in all species. Thus a few species have been shuttled between Talorchestia and Orchestia (Tattersal, 1912; Iwasa, 1939; Amanieu \& Sulvat, 1963). These situations are conceived to be caused by the weighting too much on the morphology itself. Since the form bears not only the phyletic history, but also the functional aspects, attempts to evaluate the diagnostic character from an ecological veiwpoint or in relation to the mode of life seem to be worthwhile.

According to Stebbing (1906), the genus Talorchestia is "like Orchestia, except that gnathopod I in $q$ is simple, instead of subchelate. Peraeopod 2 usually has the inner margin of the finger more sharply constricted than in allied genera," and the species have been allocated to this genus mainly by the gnathopod $I$ in the female. Reid (1918) has noted for Talorchestia deshayesii (Audouin) that both gnathopods I and II are engaged in burrowing. The gnathopod $I$ is indeed a very functional appendage and is observed to be employed in active digging in the present study for Orchestia platensis, Orchestoidea trinitatis (the status of the genus Orchestoidea is rather problematic and now in a controversy, the generic identification of this species has been done formally after the nomeclatorial rules) and Talorchestia sinensis. Gnathopod II is not used in digging, contrary to the Reid's observation. The simple structure of the gnathopod I seems to be an adaptation to the digging mode of life. On the other hand, the subchelate structure of the gnathopod I in the male seems to suggest its usability in the copulatory behavior. It was observed in Orchestia platensis that the male carried the female by use of the gnathopod I, which was hooked at the lower margin of the pereionite II of the latter. Also in Talorchestia the gnathopod I in the male is supposed to play some role in the copulatory behavior. 
As to the relations between body form, behavior and habitat, special attention has been paid on each occasion of the present collections. As a result of these observations, the following tendency was seemingly perceivable that Orchestia with a laterally compressed body form lives in narrow spaces, for example, between stones or under stranded matter or leafmold, while Talorchestia and Orchestoidea with a cylindrical body form lives in the sand. As to the Talitridae in New Zealand, Chilton (1917) also pointed out that Talorchestia are confined to sandy beaches and Orchestia, though not all species, are found under stones on rocky shore. The correlated occurence of the body form to the habitat in Orchestia may be reasonable. Then, what can be the biological meaning of the cylindrical body form in Talorchestia and Orchestoidea living on the sandy shore? The life of Talorchestia nipponensis and Orchestoidea trinitatis can be characterized by the habitat in contrast with that of Orchestia platensis; namely, the former two can be seen burrowing in the sand and independently of the wrack bed on the vast shore, and the latter under stranded matter regardless of the substratum. Stranded matter dependent life will require much locomotive power of the animals, for the fluctuation of quantity and distribution of the stranded matter are rather extensive on the shore even for the short period. Jumping behavior which provides locomotive power a lot is rather significant in such mode of life. On the contrary, for the life of the sand hoppers in the sand on the wide beach, burrowing and walking seems to be important. Because the animals must follow the depth in the sand where they can find the proper moisture which will fluctuate unceasingly in accordance with the tidal level and at dawn they must walk to find the site to dig on the flat shore where the physical conditions will change in gradient. Cylindrical body form or dorso-ventrally compressed form seems to correspond to both the burrowing and walking behavior. Because parallel correspondences are found in Haustoriidae living in the bottom sand, as pointed out by Bousfield (1970), who says, "There are indications that the broad fusiform enable an animal to burrow more deeply in the substratum..." and also in Corophiidae, some species of the family are skillful burrowers under water and are characterized by a dorso-ventrally depressed body. It is needless to say that the dorso -ventrally depressed body makes walking easier and more stable. In this connection, body broadening might correspond, to some extent, to the lateral extrusion of legs, although most of it is done by the torsion of the leg article, to support the body on land. Thus some structures including diagnostic one and their functions are seemingly diferentiated between Talorchestia and Orchestia in adaptation for their respective habitats. Namely, it may be supposed that Talorchestia and Orchestia correspond to the sandy beach and gravel or wrack habitats respectively at the generic level, and the life mode of Orchestia must have permitted it to invade the terrestrial habitat, where we can find stable leafmold habitat in the forest but do not find wide and constant sand flats except in desert too arid for crustaceans to survive.

Judging from these biological aspects, I should propose to transfer Talorchestia pachypus Derzhavin, once allocated to Orchestia platensis japonica (Tattersal) by Iwasa 

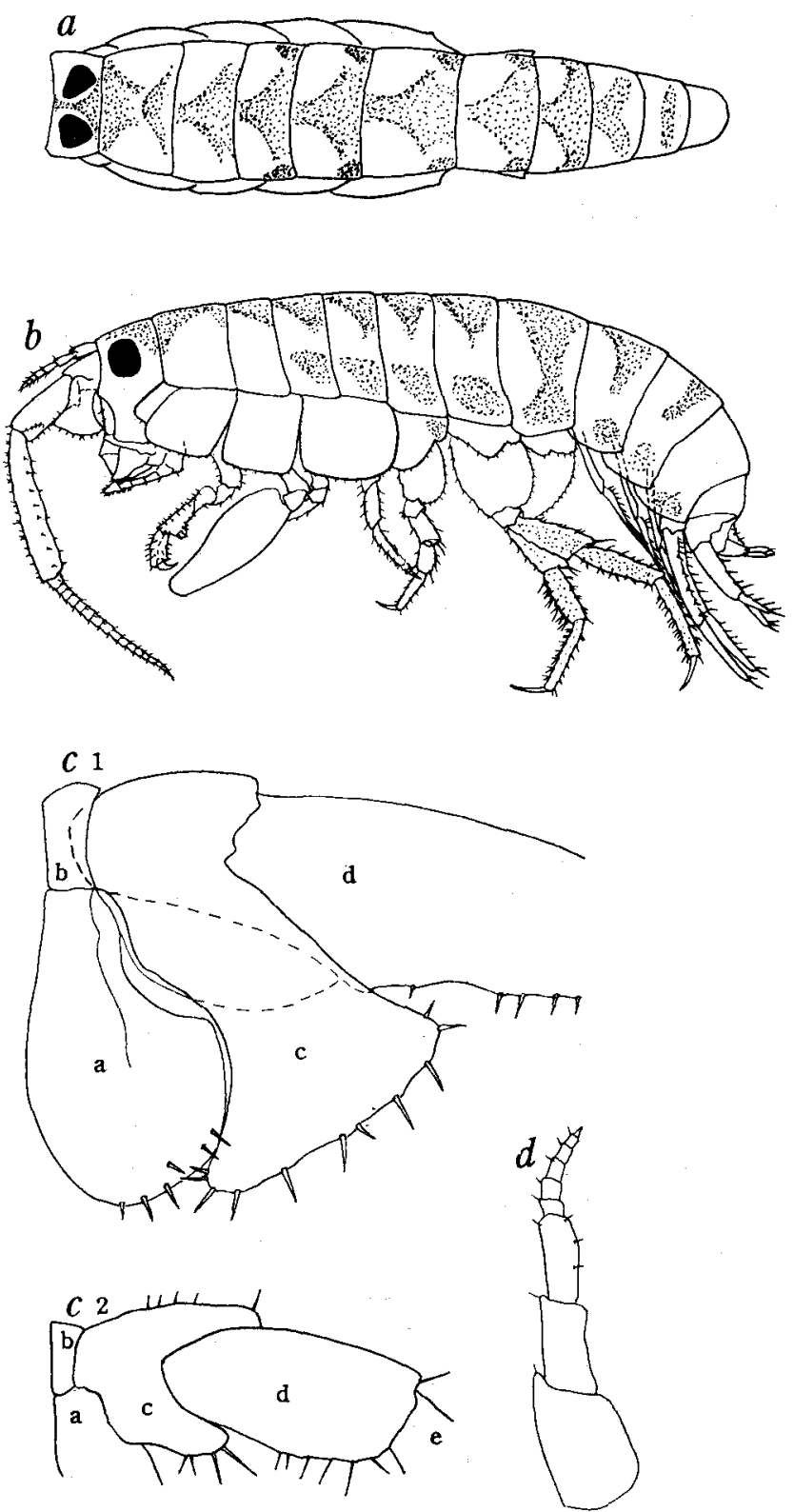

Text-fig. 1. Talorchestia sinensis, $a$, dorsal view $(\times 7.5) ; b$, lateral view $(\times 7.5) ; c$, 1, proximal part of peduncle of antenna II, male $(\times 40.5) ; c 2$, female $(\times 40.5) ; d$, antenna $I(\times 24)$. a, 1st article; b, 2nd article; c, 3rd article; d, 4th article; e, 5th article; from Shioyahama, 20 November, 1971 . 
(1939), to Orchestia. Because Talorchestia pachypus is an intermediate between Talorchestia and Orchestia in its form of gnathopod I in the females but has laterally compressed body form rather than dorso-ventrally depressed, and it prefers the gravel shore to the sandy beach as compared with Orchestia platensis, the difference in their habitat preferences will be discussed in a following paper.

\section{Talorchestia sinensis Chilton, 1925}

(Text-figs. 1-5)

Talorchestia sinensis, Chilton, 1925, pp. 283-284.

Material examined: About a dozen specimens from Shioyahama in Gobo, Wakayama Prefecture, and some from Shikoku and Yoron Island have been examined.

Description: Male slightly larger than female.

Colour milky white with a series of dark brown stripes, one on each body segment, becoming gradually indistinct posteriorly till only a lateral spot remaining on each side of pleonite III; on each pereonite the dark brown pigmentation spreading triangularly from the anterior medial line to the posterior margin and in addition with a large roughly subrectangular spot on the lateral side except pereonite I and II; 1st articale
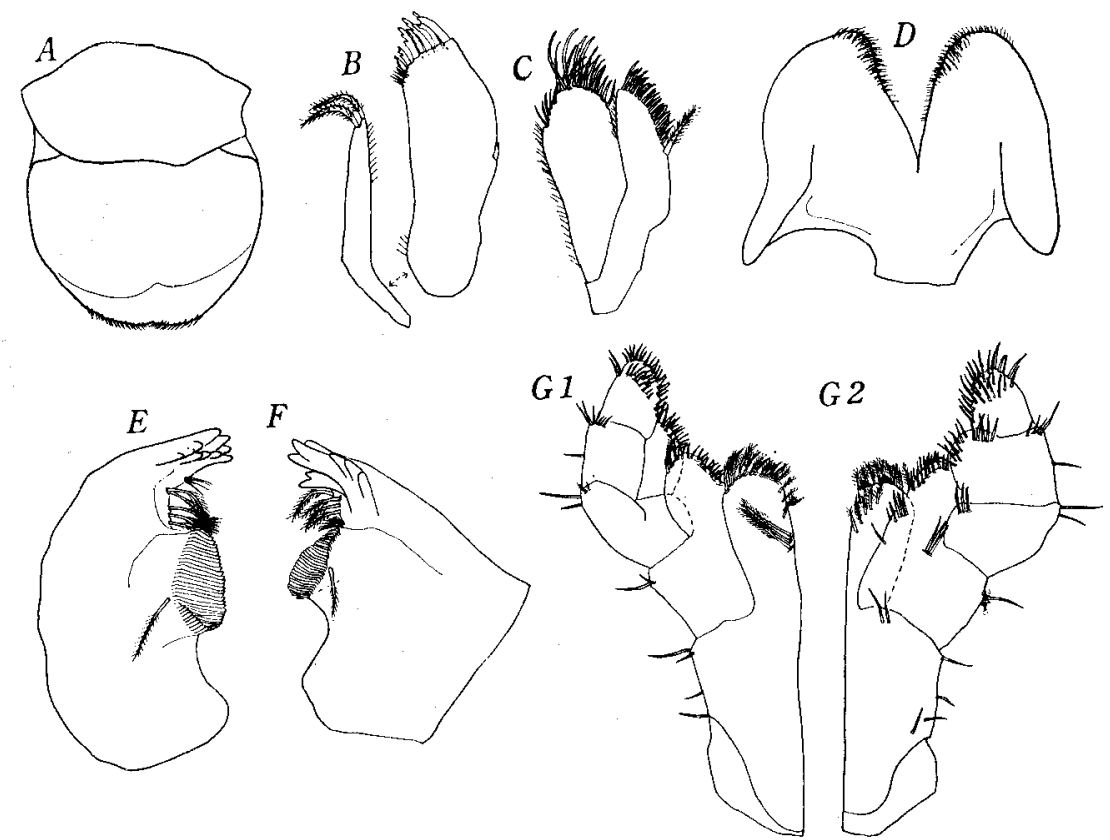

Text-fig. 2. Talorchestia sinensis, $A$, upper lip $(\times 40) ; B$, 1st maxilla $(\times 40) ; C$, 2nd maxilla $(\times 40)$; $D$, lower lip $(\times 40) ; E$, left mandible $(\times 40) ; F$, right mandible $(\times 40) ; G 1$, maxilliped, dorsal view $(\times 40) ; G 2$, ventral view ( $\times 40)$; from Shioyahama, 20 November ,1971. 


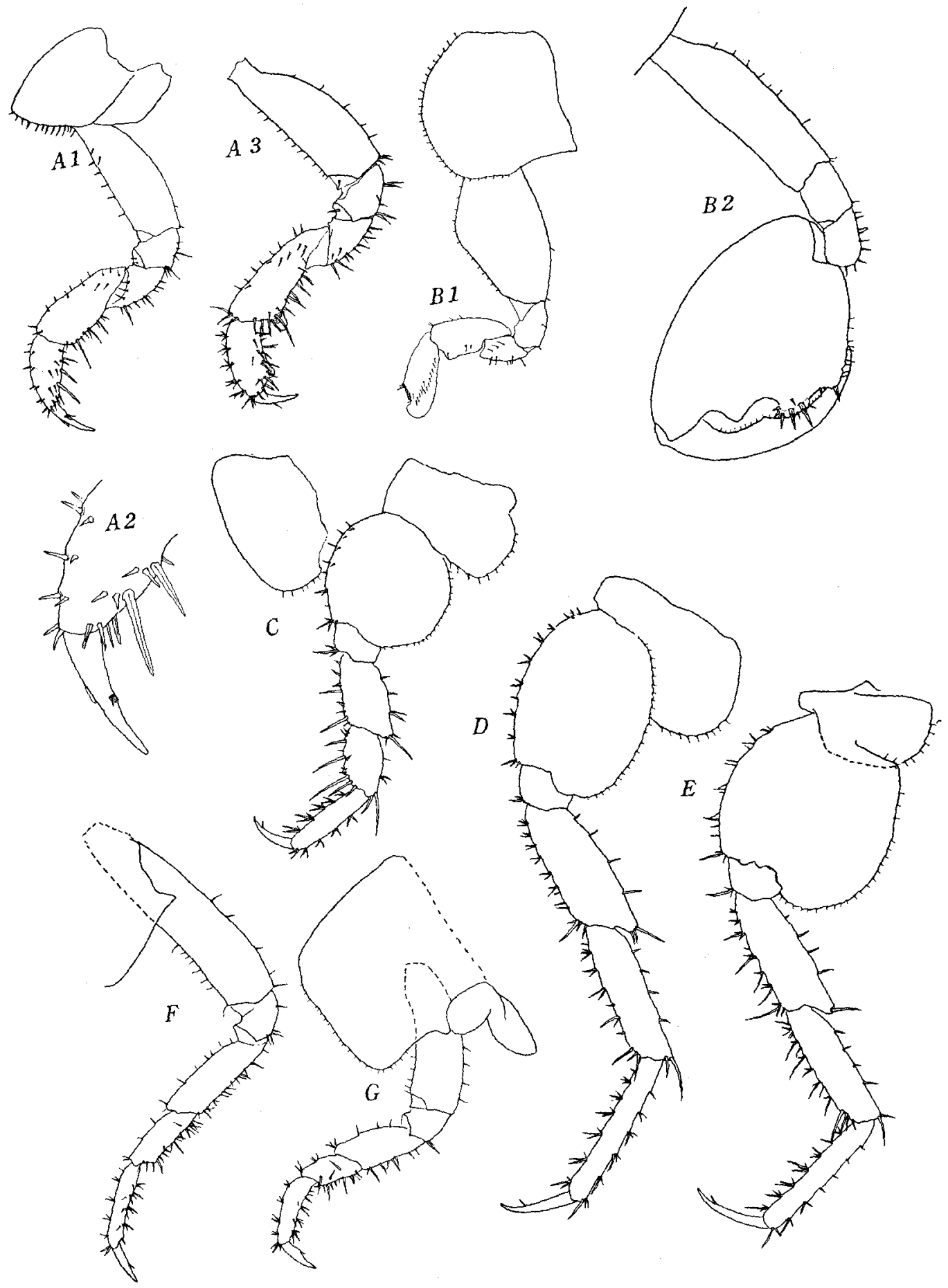


of pereiopod III furnished with a spot on the posterior side, 4 th, 5 th and 6 th articles of pereiopod IV and V faintly coloured.

Body robust, back moderately broad. Eyes large, round and black, more round in female than in male.

Anntena I not reaching 3rd article of peduncle of antenna II, three articles of peduncle about equal in length, 1st article broadest, flagellum consisted of 6 articles in adult and a little longer than 3rd article.

Antenna II longer than one-third of body, peduncle longer than flagellum in male, but almost equal in female; 1st article of peduncle produced below into a large surface to be fixed firmly $\mathrm{cn}$ the front surface, 2nd article small, 3rd article in male stretching downward a large triangular plate fringed with several short spines, in female the plate stretching foreward to about the proximal third of 4th article, 4th article with a small protrusion on the under side especially in male, which is wholly covered by triangular plate of 3 rd article, 5th article much longer than 4th article and armed with short spines, flagellum consisted of about 20 articles in adult.

Mouth parts normal.

Gnathopod I in male spinous and subchelate; 5 th article longer than 6 th article, each bearing a narrow subapical pellucid lobe, a little more remarkable in the former; 7 th article longer than palm of 6th article; 5 th and 6th articles in female simple and bearing no pellucid lobe. Gnathopod II in male large and well developed; 2nd article slender; 3rd and 4th articles short and almost equal in length, the latter furnished with setae; 5th article small and triangular; 6th article large and expanded laterally into a triangularly oval shape, palm defined by a small protuberance with a pair of spines, bearing two protrusions, one situated near the hinge with 7 th article, tringular and without any armature, the other process rather round and with several strong spines; 7th article curved and longer than the palm of 6th article, with two gentle concavities with minute spinules on the grasping margin. In female, 2nd article expanded in the middle on the anterior margin; 6th article almost equal to 5th article in length, with a broad pellucid lobe extended over small 7 th article.

Pereiopod I slender. Pereiopod II a little more robust than pereiopod I, 7th article narrowed sharply in the distal half on the inner margin. Pereiopod III armed with long spines, 2nd article expanded postreiorly. Pereiopod IV longest, 2nd article exapnded posteriorly. Pereiopod V similar to pereiopod IV, but 2nd article expanded more widely than pereiopod IV.

Pleopod well developed, flagellum longer than peduncle and consisted of about 14 articles.

Text-fig. 3. Talorchestia sinensis, A 1, gnathopod I of female $(\times 16) ; A 2$, distal part of gnathopod of female $(\times 50) ; A 3$, gnathopod I of male $(\times 16) ; B 1$, gnathopod II of female $(\times 16) ; B 2$, gnathopod II of male $(\times 16) ; C$, pereiopod III $(\times 16) ; D$, pereiopod IV $(\times 16)$; $E$, pereiopod $\mathrm{V}(\times 16) ; F$, pereiopod I $(\times 16) ; G$, pereiopod II $(\times 16)$; from Shioyahama, 20 November, 1971 . 
Epimeral plate I roughly subtriangular. Plate III subrectangular. Plate II intermediate between preceding two in shape, the pasterior margin with several setae in all plates.

Uropod I biramous, peduncle with strong spines on the dorsal edges, inner ramus with marginal and apical spines, outer ramus only with apical spines. Uropod II biramous, both rami with spines marginally and apically. Uropod III uniramous;
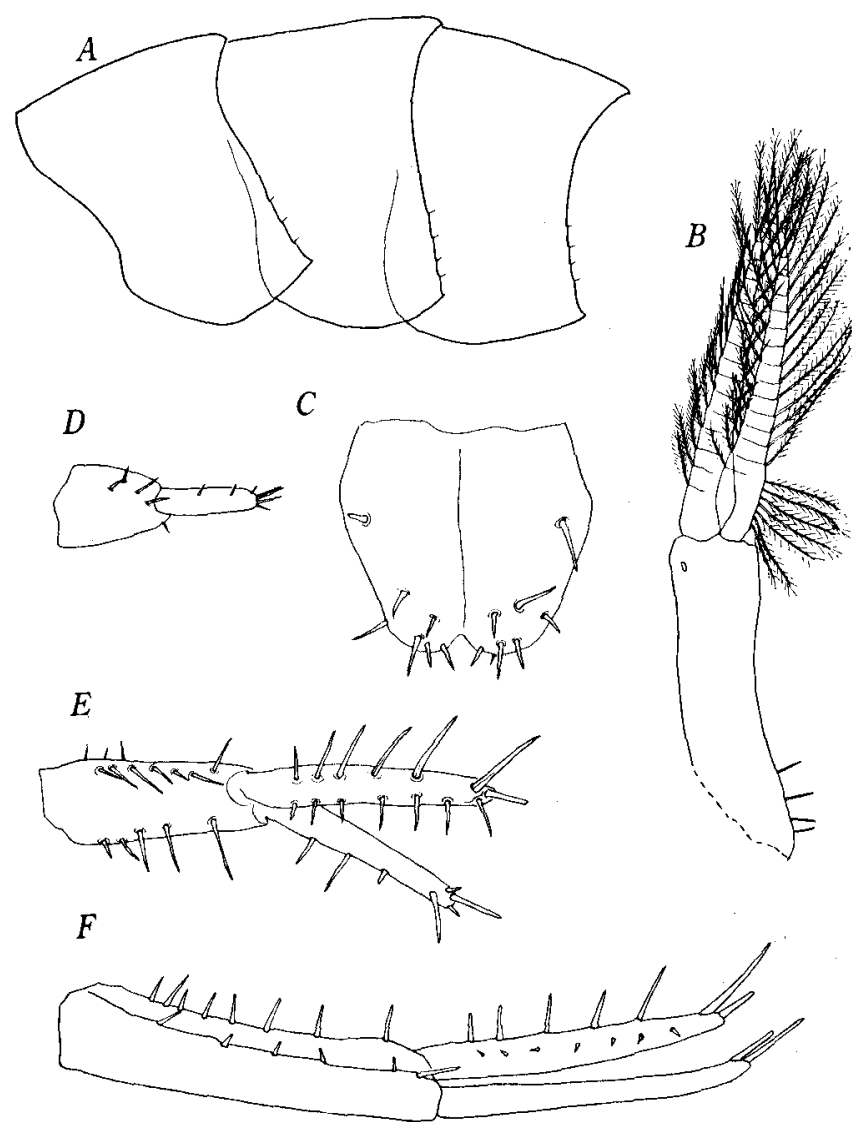

Text-fig. 4. Talorchestia sinensis, $A$, epimeral plates $(\times 13.5) ; B$, pleopod I $(\times 27)$, $C$, telson $(\times 50)$; $D$, uropod III $(\times 27) ; E$, uropod II $(\times 27) ; F$, uropod I $(\times 27)$; from Shioyahama, 20 November, 1971.

ramus about equal to peduncle in length, bearing a few setae.

Telson longer than width, with a notch on the posterior apex and with several spines on the surface and margin.

Habitat: According to the observations made at Shioyahama and Yoron Island, this species seems to be restricted under stranded matter on the sandy shore. At Shioyahama, it was found burrowing in the substratum of rather fine sand, but no 
specimen was captured in the sand at the site with no stranded matter scattered above. In Yoron Island, they occurred under stranded matter on the shore of foraminiferous sand.

Distribution: So far as I am aware, the present species has only been reported once

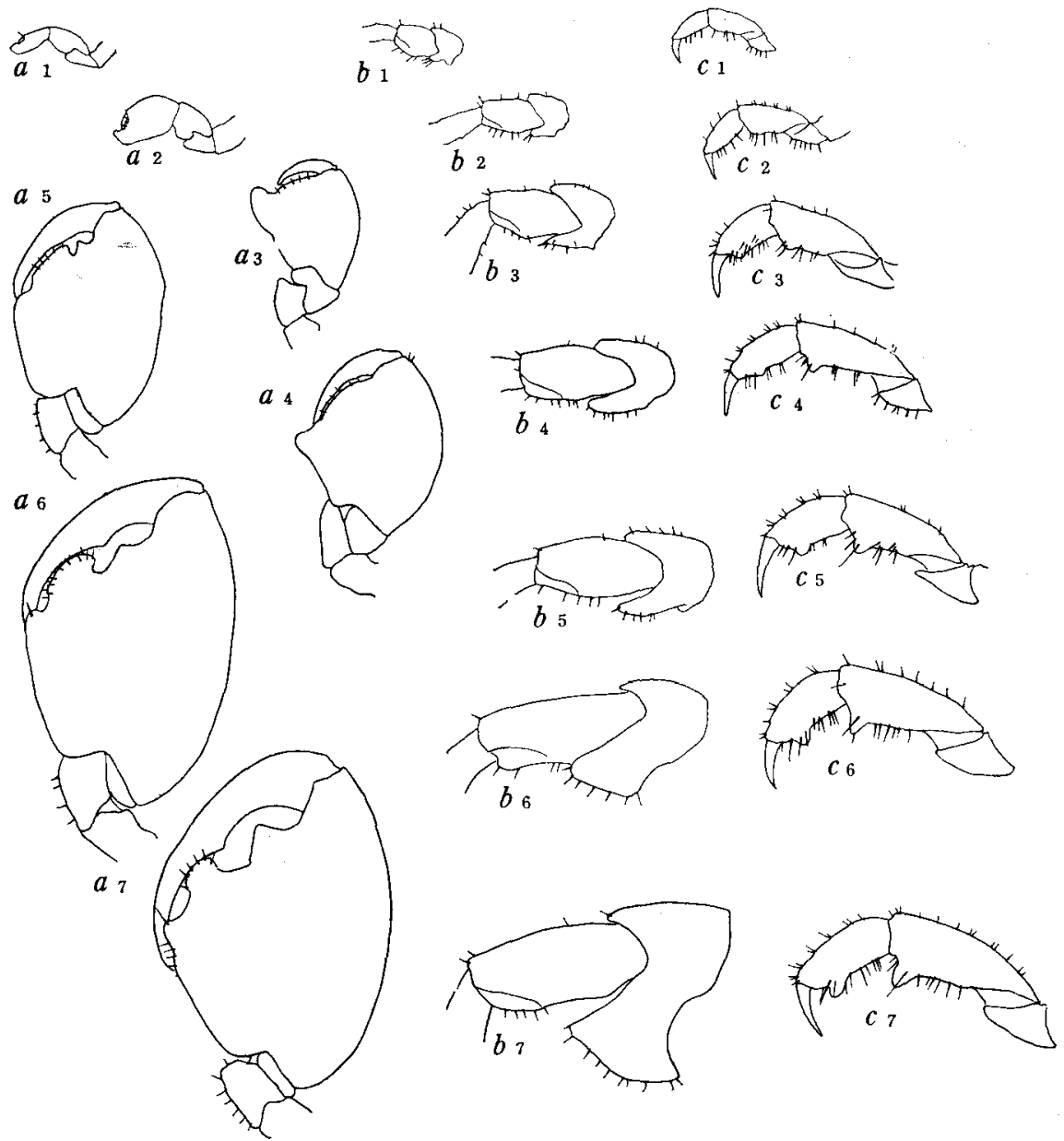

Text-fig. 5. Talorchestia sinensis, successive change of secondary sexual characters; a, gnathopod II $(\times 16) ; b$, peduncle of antenna II $(\times 16) ; c$, gnathopod I $(\times 16) .1$, juvenile, about $6 \mathrm{~mm} ; 2$, male, about $7 \mathrm{~mm}, 3$, male, about $9 \mathrm{~mm} ; 4$, male, about $10 \mathrm{~mm} ; 5$, male about $11 \mathrm{~mm}$; 6 , male, about $12 \mathrm{~mm} ; 7$, male, about $13 \mathrm{~mm}$. 1-2 from Yoron Island, 1 August, 1971; 3-7 from Shioyahama, 20 November, 1971.

from Ghina by Chilton (1925) based on the specimens sent from Amoi University, but no further exact locality was mentioned. In Japan, the species occurs rather sparsely along the Pacific coast up to the Kii district. Localities: Shioyahama in Gobo, in Wakayama Prefecture; Komatsujima in Tokushima Prefecture and Naruto in Ka- 
H. MORINO

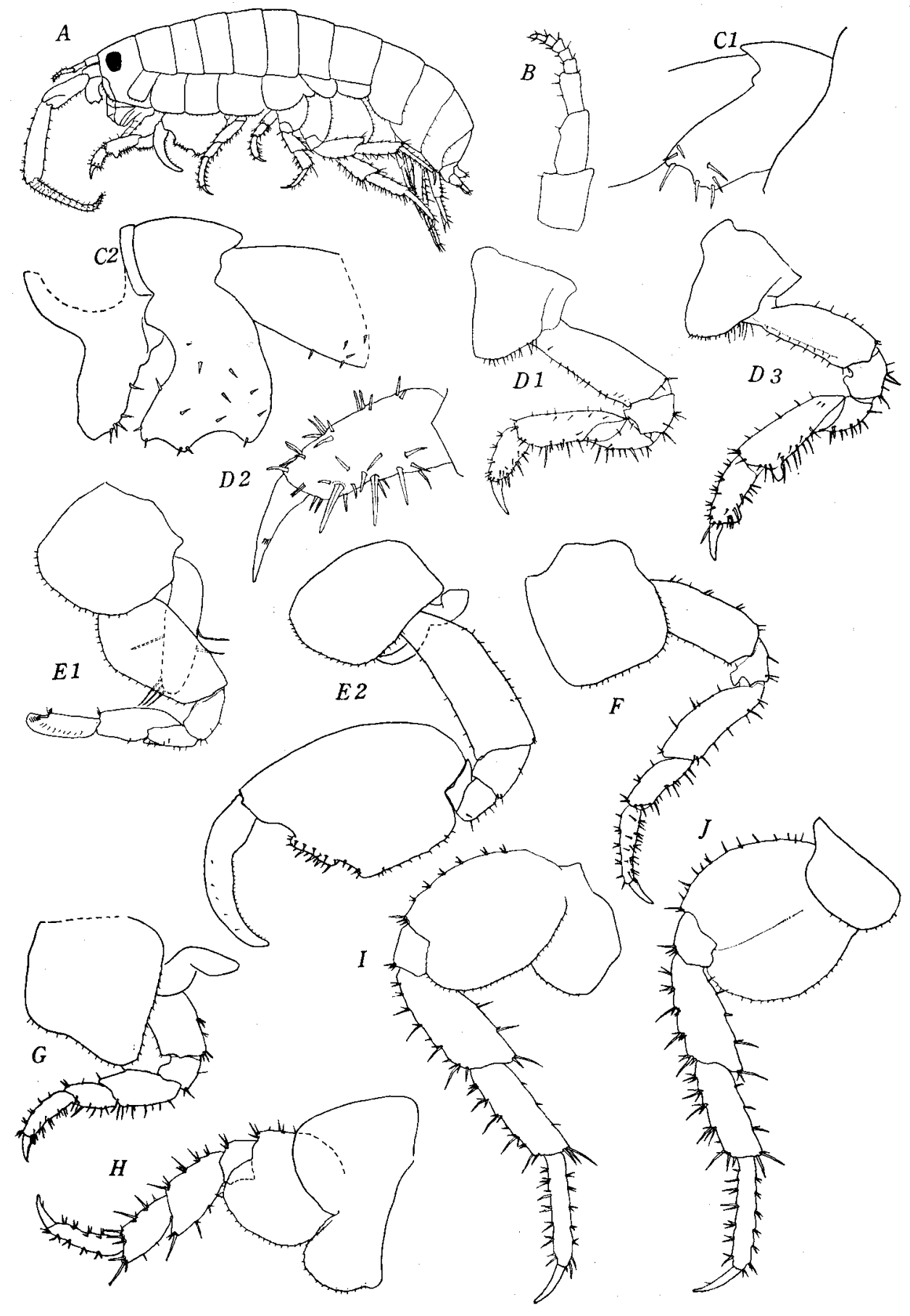


gawa Prefecture in Shikoku Island. Hakebinahama and Tomori Bay in Yoron Island.

Remarks: Since the original description was made on male specimens only, Chilton was not sure of the genus. Now, however, the simple structure of the gnathopod I in the female specimen has proved his generic allocation. Just as he suggested, the peculiar downward plate of the 3rd article of the peduncle of the antenna II is a secondary sexual character. Successive changes of the plate and gnathopods I and II are depicted in text-figure 5 .

The present species can be easily distinguished by the possesion of a large triangular plate of the 3rd article of the peduncle of the antenna II from other congeneric species, except Talorchestia nipponensis $\mathbf{n}$. sp. which bears, however, marginal spines on the outer ramus of the uropod I that the present species lacks.

\section{Talorchestia nipponensis, n. sp.}

(Text-figs. 6-8)

Material examined: Several specimens from Nijigahama in Yamaguchi Prefecture, as well as some from Awa-kominato in Chiba Prefecture and Tosa-irino in Kochi Prefecture have been examined.

Description: Body of normal shape, back slightly broad. Eyes not so large, slightly oblong and black.

Antenna I not reaching 3rd article of peduncle of antenna II except in juvenile specimens; three articles of peduncle nearly equal in length, of which 2nd longest and 1st broadest; flagellum consisted of 6 articles in adult, longer than 3rd article and shorter than 2nd and 3rd articles combined.

Antenna II longer than one third of the body length in male, but much shorter in female; 1st article of peduncle produced below a broad plate attached on the face of head; 2nd article small and indistinct; 3rd article in male produced below a slightly curved plate on outerlateral side, lower edge of which bears two concavities with spinules between them and on the corners, as well as on the surface, in female the plate small and produced obliquely; 4th article bearing a big channel on the lower side which permits the wide angle movement of 5th article; 5 th article remarkably developed in male, longer than twice of 4th article, becoming thicker distally in female much shorter and more slender than in male, armed with short spines in both sexes; flagellum consisted of about 20 articles in adult.

Text-fig. 6. Talorchestia nipponensis, n. sp. $A$, lateral view $(\times 5) ; B$, antenna $\mathrm{I}(\times 16) ; C 1$, 3rd article of antenna II of female $(\times 50) ; C 2$, proximal articles of peduncle of antenna II of male $(\times 127)$; $D$ 1, gnathopod I of female $(\times 13.5) ; D 2$, distal parts of gnathopod I of female $(\times 40) ; D 3$, gnathopod I of male $(\times 13.5)$; $E 1$, gnathopod II of female $(\times 13.5)$; $E 2$, gnathopod II of male $(\times 13.5) ; F$, pereiopod IV $(\times 13.5) ; J$, pereiopod V $(\times 13.5)$; male $15.0 \mathrm{~mm}$, female $13.5 \mathrm{~mm}$, from Nijigahama, 10 May, 1971. 

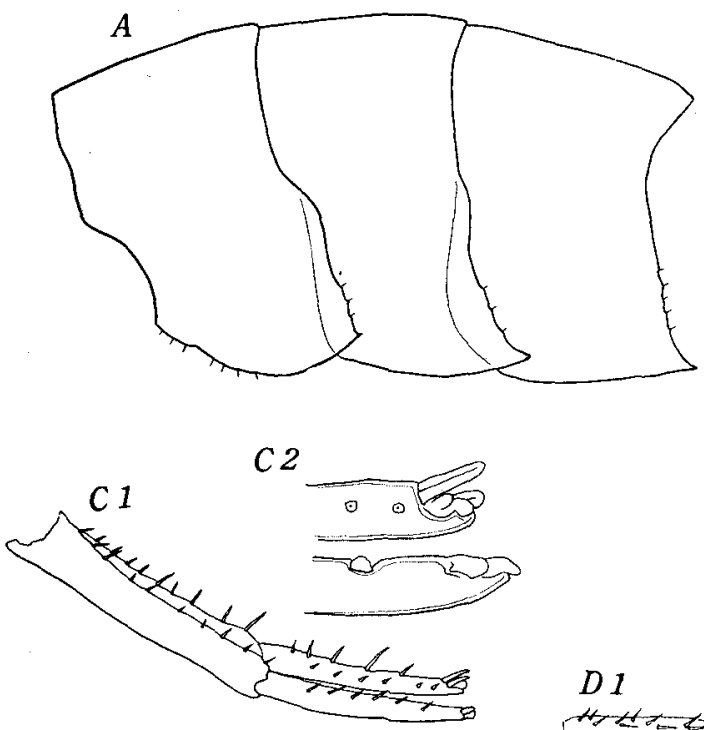

$D 1$
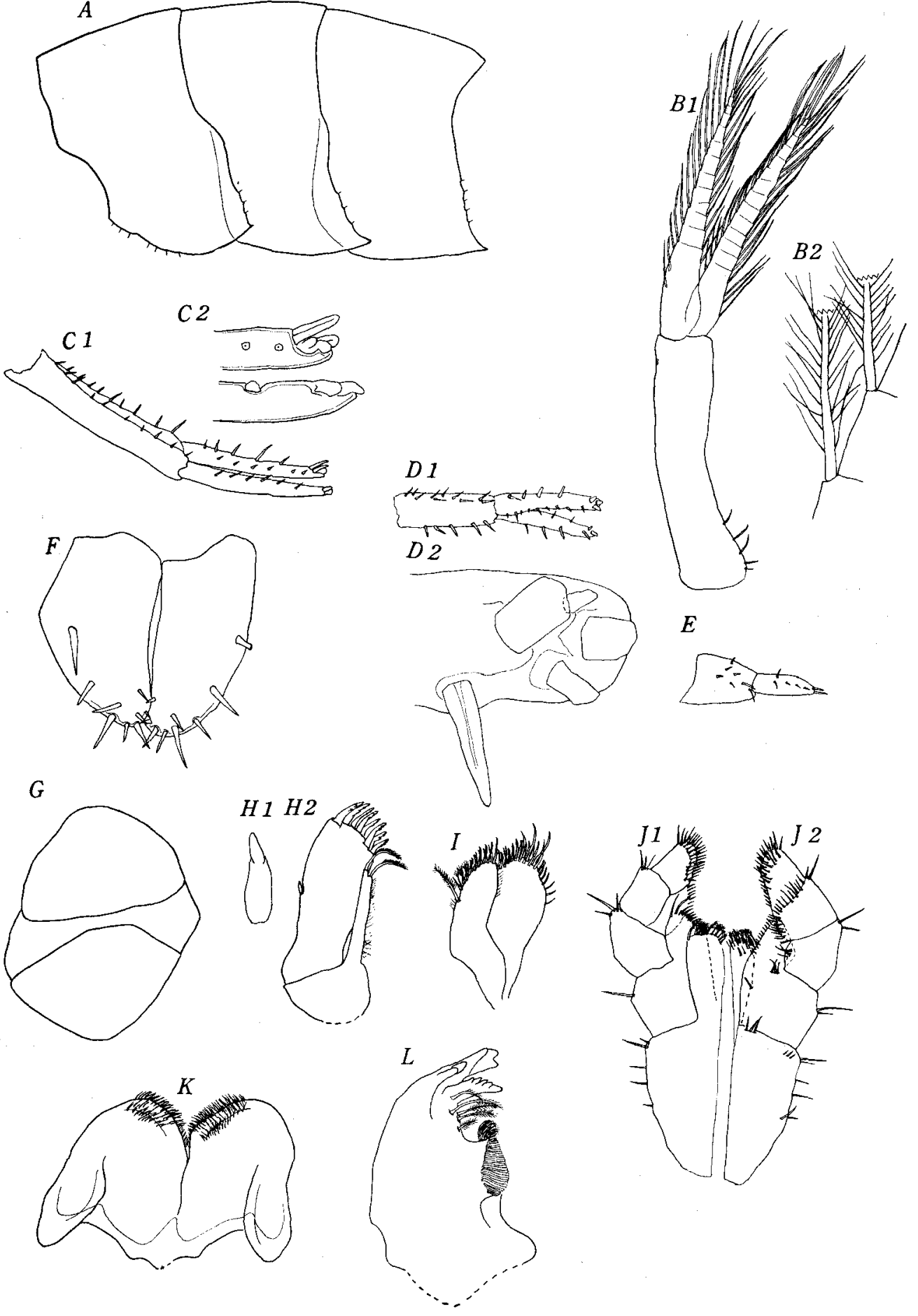
Mouth parts normal.

Gnathopod I in male spinous and subchelate; 5 th article much longer than 6 th article, both bearing subapical pellucid lobes, but that of 5 th article more remarkable; 7 th article longer than palm of 6 th article; in female simple and without pellucid lobe. Gnathopod II in male very largely developed; 2nd article broad, 3rd article longer than 4th article, 5th article small, 6th article massive and oblong oval, palm oblique bearing a plateau in the middle with several strong spines, the plateau slightly concaved, anterior margin bearing setae, defined by a small protuberance, 7 th article longer than palm of 6 th article, bearing a small concavity at the proximal part of grasping margin, distal part from the convexity bearing small setae; in female, 2nd article expanded in the middle with several small setae, 6th aricle elongate with a broad pellucid lobe stretching over small 7 th article.

Pereiopods I and II very much like each other, but the latter shorter than the former, 7 th article of pereiopod II constricted sharply in the inner margin. Pereiopod III much shorter than pereiopod IV, and V, with 2-lobed 1st article, pereiopod IV very much like pereiopod $\mathrm{V}$ except the expansion of $2 \mathrm{nd}$ article of the latter wider than the former.

Pleopods well developed; flagellum almost equal to peduncle in length, consisted of about 13 articles.

Epimeral plate I produced slightly in the middle of ventral margin, bearing small setae on the antero-ventral corner; plateII and III similar, subrectangular and pointed at the postero-ventral corner, posterior margin of these three plates equipped with several setae.

Uropod I biramous, peduncle longer than rami, bearing spines on the dorsal edges; both rami with marginal and apical spines, some of the apical spines short and blunt which is peculiar to fully grown adult, though not for all. Uropod II biramous, bearing many spines on the dorsal edges of peduncle; both rami with spines marginally and apically, some of the apical spines very short and blunt, as in uropod I. Uropod III uniramous, peduncle nearly equal to ramus in length, both with several setae.

Telson with a notch at the posterior apex, bearing short spines on the surface and margin.

Holotype: Male, $15 \mathrm{~mm}$, collected on the shore of Nijigahama, Hikari City in Yamaguchi Prefecture, 10 May, 1971; deposited at the Seto Marine Biological Laboratory (SMBL-Type 240).

Allotype: Female, $13.5 \mathrm{~mm}$ (SMBL-Type 241).

Text-fig. 7. Talorchestia nipponensis, n. sp. $A$, epimeral plates $(\times 13.5) ; B 1$, pleopod I $(\times 27)$; $B 2$, setae of pleopod I $(\times 160) ; C 1$, uropod I $(\times 16) ; C 2$, distal parts of uropod I $(\times 50)$; $D 1$, uropod II $(\times 16) ; D 2$, distal parts of uropod II $(\times 160) ; E$, uropod III $(\times 27) ; F$, telson $(\times 50) ; G$, upper lip $(\times 40) ; H I$ vestigial palp of maxilla I $(\times 300) ; H 2$, maxilla II $(\times 40) ; 1$, maxilla II $(\times 40) ; J 1$. ventral view of maxilliped $(\times 40) ; J 2$, dorsal view of maxilliped $(\times 40)$; $K$, lower lip $(\times 40) ; L$, left mandible $(\times 40)$; male $15.0 \mathrm{~mm}$ from Nijigahama, 10 May, 1971. 
$a_{1}$
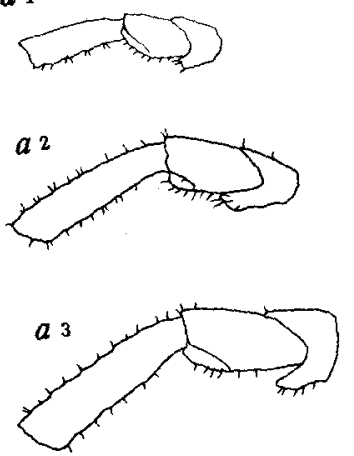

$b 1$

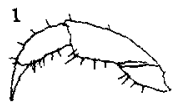

(r+t)

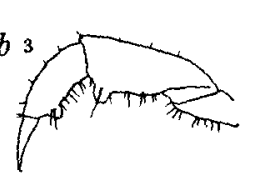

c 1

Exs
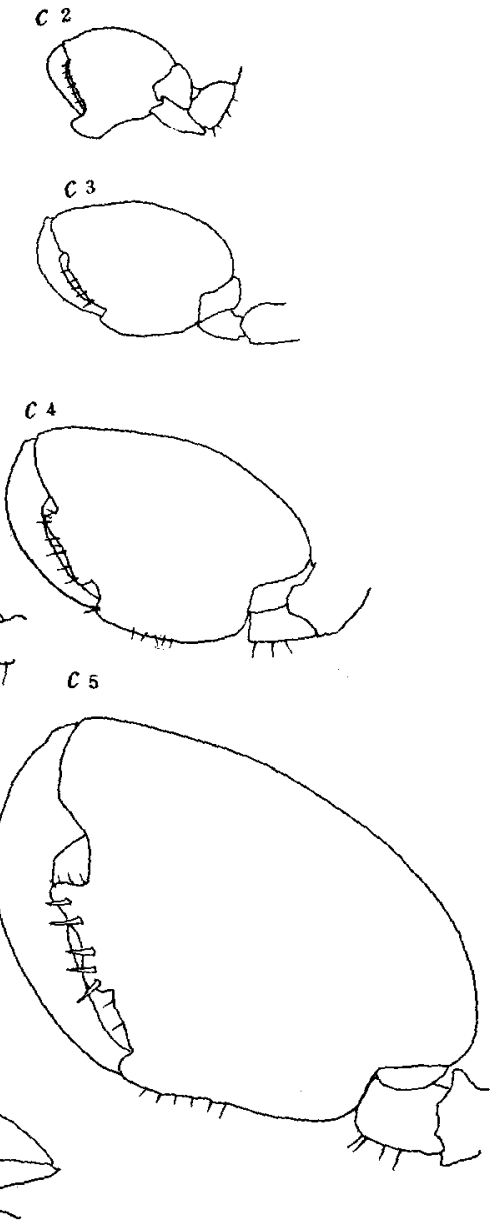

C 6
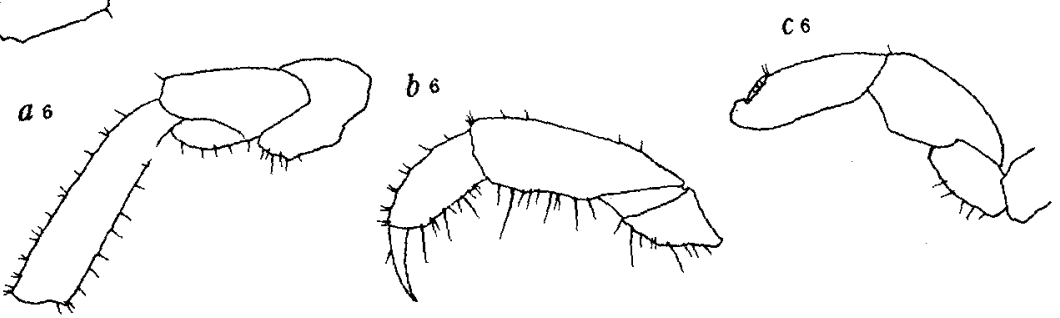
Habitat: Observations were carried out at several localities..

The species occurs on the sandy beach. On the widely stretching shore of fine sand, it was found burrowing deeply in the sand. For example , at Tosa-irino in Kochi Prefecture, the species was restricted to the sand with stranded matter above in the supralittoral zone, but was captured in the sand along the high tide line at clear sites. In some localities of such shores, Orchestoidea trinitatis was caught together with the present species. On the other hand, the species was also found under stranded matter on shores of coarse sand, together with Orchestia platensis in some localities. In such cases, at Awa-kominato in Chiba Prefecture, for example, the present species was not so strictly restricted to the wrack beds as Orchestia platensis.

Distribution: The present new species occurs in the middle of Japan from northern Kyushu up to the middle of Honshu. Localities: Tsuyazaki in Fukuoka Perfecture, Sumiyoshihama of Kitsuki in Oita Prefecture, Tosa-irino in Kochi Prefecture, Nijigahama in Yamaguchi Prefecture, Hamashima in Mie Prefecture, Takahama in Fukui Prefecture and Oarai and Nakaminato in Ibaragi Prefecture.

Remarks: Peculiarly produced plate of 3rd article of peduncle of antenna II is seen only in the present species and Talorchestia sinensis in the genus Talorchestia. This seems to suggest that both species are more or less related to each other. But the present species can be distinguished from Talorchestia sinensis in the following characters:

1) the presence of marginal spines on the outer ramus of uropod $I$,

2) the presence of setae on the ventral margin of epimeral plate $I$ in both sexes,

3) the presence of two shallow concavities on the lower margin of peduncle of antenna II,

4) the presence of a plateau on the palm of gnathopod II in male. Succesive change of these secondary sexual characters are depicted in text-figure 8.

\title{
Orchestoidea trinitatis Derzhavin, 1937
}

(Text-figs. 9-11)

\author{
Orchestoidea trinitatis Derzhavin, 1937, pp. 88, fig. 1. \\ Talorchestia brito, Iwasa, 1939, pp. 273-276, figs. 13-15, Pt. XV. \\ $T$. brito, Stephensen, 1944, pp.65-69, figs. 22-23. \\ T. brito, Gurjanova, 1951, pp. 809-810, fig. 563. \\ Orchestoidea brito, Bulycheva, 1957, pp. 134-135, fig. 49.
}

Material examined: Specimens from Hatakejima Island in Tanabe Bay, Komatsujima Tokushima Prefecture, Oshamanbe in Hokkaido and Sumiyoshihama in Fukuoka Prefecture have been examined.

Text-fig. 8. Talorchestia nipponensis, $\mathrm{n}$. sp. Successive change of secondary sexual characters; $a$, peduncle of antenna II $(\times 16) ; b$, gnathopod $\mathrm{I}(\times 16) ; c$, gnathopod II $(\times 16) ; 1$, juvenile, $7.5 \mathrm{~mm}$; 2 male $10.0 \mathrm{~mm} ; 3$, male $9.4 \mathrm{~mm} ; 4$, male, $12.0 \mathrm{~mm} ; 5$, male, $15.0 \mathrm{~mm} ; 6$, female, $15.0 \mathrm{~mm} ; 1-5$ from Tosa-irino, 29 September 1971, 6 from Awa-kominato, 30 June, 1971. 


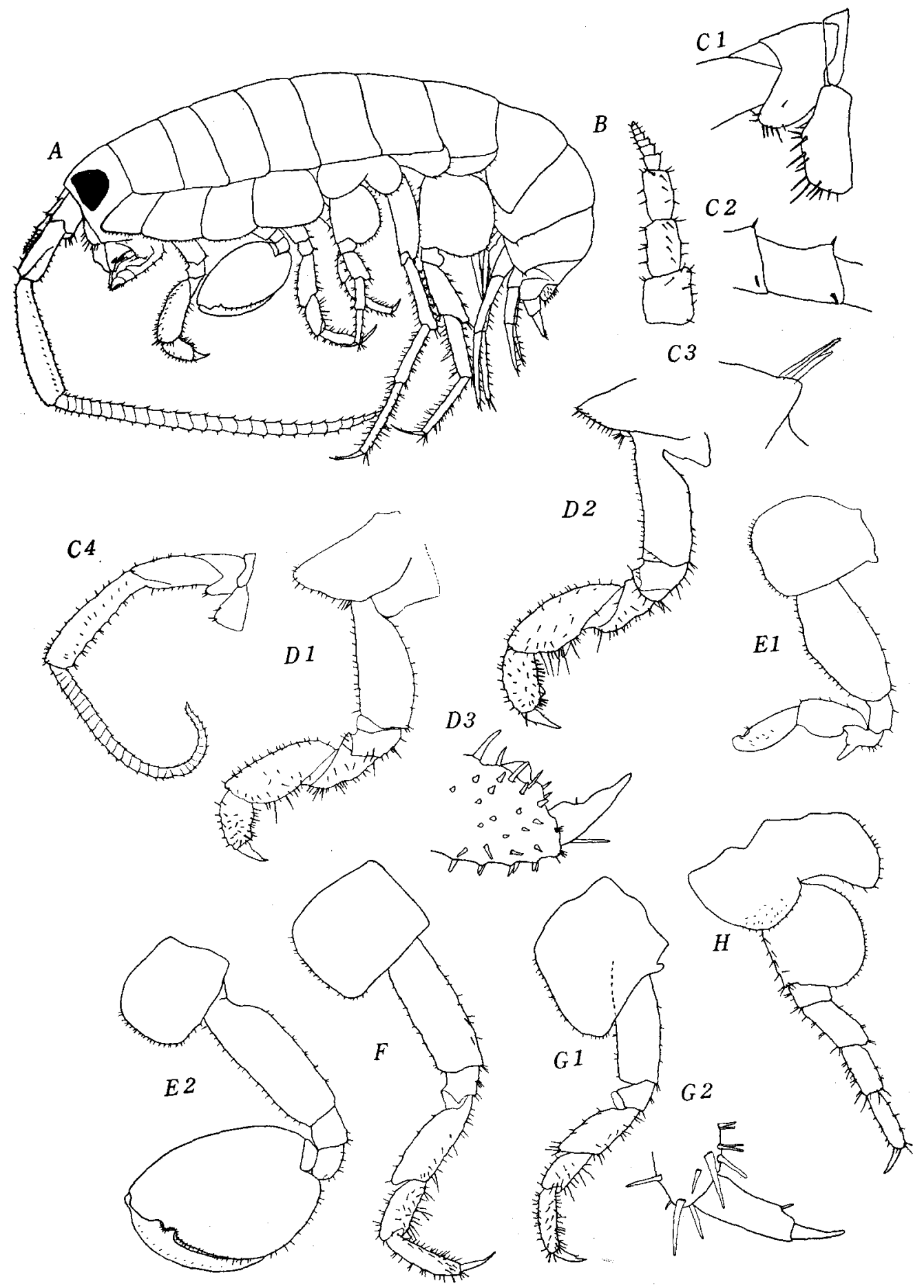


Description: Male larger than female.

Body large, back moderately broad. Eyes large semi-circular and black.

Antenna I not reaching 3rd article of peduncle of antenna II; three articles of peduncle nearly equal in length, each armed with spinules, among which 3rd article shortest and broadest; flagellum slightly longer than 3rd article of peduncle consisted of 6 articles in adult.

Antenna II longer than half of body length in male, but shorter than it in female; peduncle stout, 1st article fixed to face, 2nd article small, 5th article longest and longer than 3rd and 4th articles combined, each armed with spinules; flagellum consisted of about 30 articles in adult almost twice as long as peduncle in male and nearly equal to peduncle in female

\section{Mouth parts normal.}

Gnathopod I in male stout and spinous, feebly subchelate, 2nd article nearly equal to 5 th article which is almost twice of 6 th article, 5 th article with a small subapical pellucid lobe, armed with many blunt spinules, 7th article stout, longer than small palm of 6th article; in female almost the same as in male except lacking pellucid lobes at the subapical portion of 5 th article. Gnathopod II in male very largely developed, 6 th article with a small concavity near the hinge corresponding to small protuberance of 7 th article, a conical process on 4 th article not constant, some specimens bearing it on one side only; in female 2nd article slightly swollen in the middle, 4th article with conical process constantly, 6th article with broad pellucid lobe stretching over small 7 th article.

Pereiopod I-V spinous, of which pereiopod V longest and II, III rather short, expansion of 2nd article of pereiopod III-V most remarkable in pereiopod V.

Pleopod normal, peduncle stout, armed with spines on the outer margin; flagellum nearly equal to peduncle in length, consisted of about 12 articles.

Epimeral plate I slightly subtriangular with setae at ventro-posterior corner, plate II and III almost rectangular at ventro-posterior corner, but the former slightly swollen at the ventral margin, both plates with several long spines at the corner and many setae on the posterior margins.

Uropod I biramous, peduncle nearly equal to rami with many spines on the dorsal edges, outer and inner rami with apical and marginal spines. Uropod II biramous, peduncle shorter than rami, with spines on the dorsal edges, both rami with marginal and apical spines, apical spines not sharp and rather flat. Uropod III uniramous,

Text-fig. 9. Orchestiodea trinitatis, $A$, lateral view $(\times 5) ; B$, antenna $\mathrm{I}(\times 13.5) ; C 1$, proximal airtcle of antenna II $(\times 16) ; C 2$, article of antenna II $(\times 27) ; C 3$, spinules of article of antenna II $(\times 160) ; C 4$, antenna II of female $(\times 9) ; D 1$, gnathopod I of female $(\times 9) ; D 2$, gnathopod I of male $(\times 9) ; D 3,6$ th and 7 th articles of gnathopod I of male $(\times 27) ; E 1$, gnathopod II of female $(\times 9) ; E 2$, gnathopod II of male $(\times 9) ; F$, pereiopod I $(\times 9) ; G 1$, pereiopod II $(\times 9) ; G 2$, 6th and 7 the articles of pereiopod II $(\times 27) ; H$, pereiopod III $(\times 9)$ : Male, $21.4 \mathrm{~mm}$; female, $18.9 \mathrm{~mm}$, from Hatakejima, 15 February, 1972. 
H. MORINo

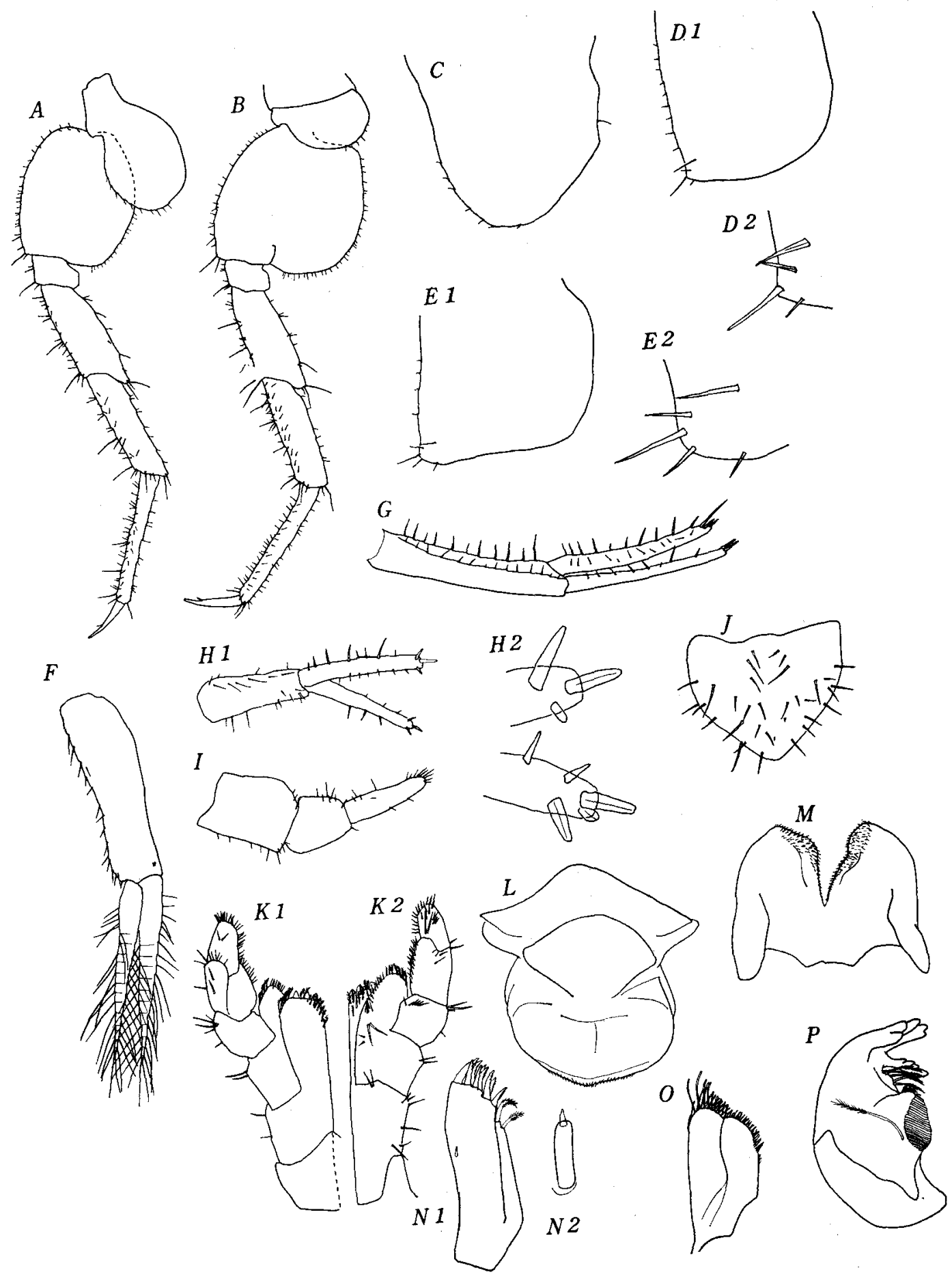


ramus shorter than peduncle, both, especially the terminal portion of ramus, armed with setae.

Telson subtriangular, with many spines on the surface and margin.

Habitat and behavior: Observations were made at several localities. The present species occurs on the wide beach of rather fine sand, regardless of exposed or protected coast, and lives burrowing in the sand; thus, its micro-distribution is quite independent of stranded matter. This fact has been proved by a series of intensive long-term observations made at Rinkai shore near the Seto Marine Biological Laboratroy. At Hatakejima Island, the animals were found appearing above the surface on the shore at night in February, but in the daytime they have never been witnessed appearing from the substratum. In captivity, they have appeared from the sand and jumped around actively at night, but no individual is coming outside the sand in the morning. On the contrary, at Oshamanbe in Hokkaido on 19 June, 1971, very many animals were found jumping and walking actively at the surging area just before noon in the sunshine. Some of them grasped rather big flies or caprellids. This was a sole experience that $I$ have sighted them on the beach during the daytime.

When the shore has a lot of stranded matter, Orchestia platensis was caught with the present species, apparently the former lives under the wrack bed and the latter in the sand, although in such a case, population density of Orchestia platensis seems to be rather low. On some shores, for example, at Tsuyazaki, Sumiyoshihama and Nakaminato, they were captured with Talorchestia nipponensis $\mathrm{n}$. sp.

Distribution: The species occurs from southern Kyushu to northern Hokkaido in Japan. Bulycheva (1957) reported it from Kamchatka Peninsula and Sakhalin.

Remarks: The present species well accords with the descriptions of Talorchestia brito given by Iwasa (1939) and of Orchestoidea brito by Bulycheva. Stephensen (1944) remarked the following differences of female specimens from Kamuikotan, Etorofu Island (c. $45^{\circ} \mathrm{N} ., 148^{\circ} \mathrm{E}$.), from the descriptions by Iwasa.

1) "eyes circular, not semi-circular in outline"; as I examined several specimens from Sumiyoshihama in Kyushu, Hatakejima in Wakayama Prefecture and Oshamanbe in Hokkaido, no female had circular eyes.

2) "Antenna I reaches towards the apex of the penultimate joint of the peduncle of antenna 2, flagellum has 7 joints. Antenna 2 is as long as the head +4 anterior body segments or a trifle longer,"; these features, particularly their length and the number of articles of the flagellum vary with size and age.

Text-fig. 10. Orchestoidea trinitatis, $A$, pcreiopod IV $(\times 9) ; B$, pereiopod V $(\times 9)$; $C$, epimeral plate I $(\times 16) ; D 1$, epimeral plate II $(\times 16) ; D 2$, ventro-posterior corner of epimeral plate II $(50) ; E 1$, epimeral plate III $(\times 16) ; E 2$, ventro-posterior corner of epimeral plate III $(\times 50) ; F$, pleopod I $(\times 16) ; G$, uropod I $(\times 13.5) ; H 1$. uropod II $(\times 13.5) ; H 2$, distal parts of uropod II $(\times 50)$; $I$, uropod III $(\times 16) ; J$, telson $(\times 13.5) ; K 1$, dorsal view of maxilliped $(\times 27) ; K 2$, ventral view of maxilliped $(\times 27) ; L$, upper lip $(\times 13.5) ; M$, lower lip $(\times 13.5) ; N 1$, maxilla $I(\times 13.5) ; N 2$, vesti gial palp of maxilla I $(\times 160)$; $O$, maxilla II $(\times 13.5)$; $P$, left mandible $(\times 13.5)$. Male, $21.4 \mathrm{~mm}$, from Hatakejima, 15 February, 1972. 

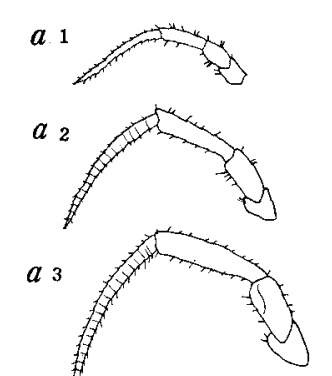

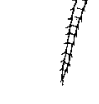
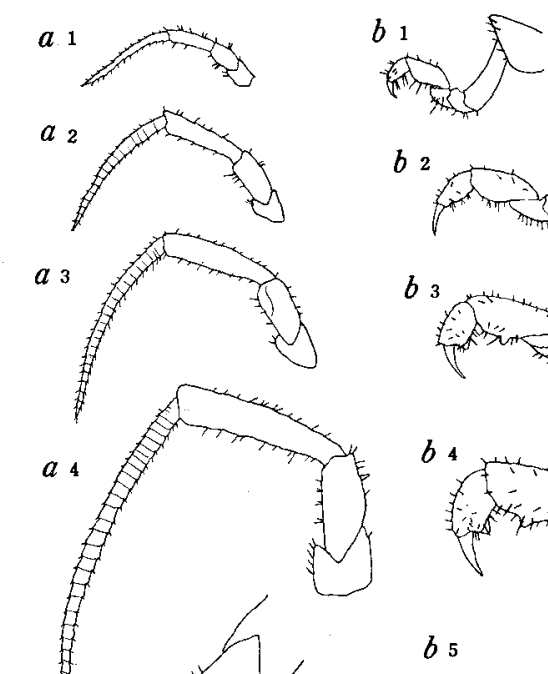

b 2

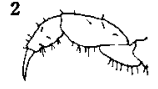

$b_{3}$

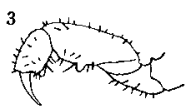

b 4

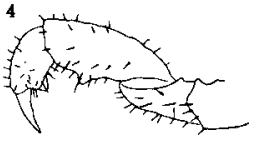

b5

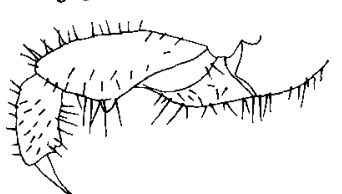

$a 5$

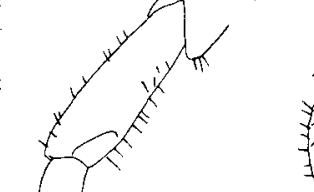

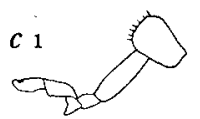
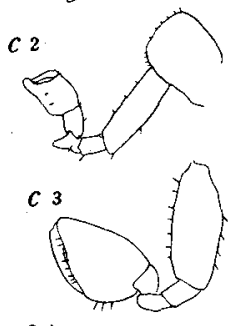

c 4

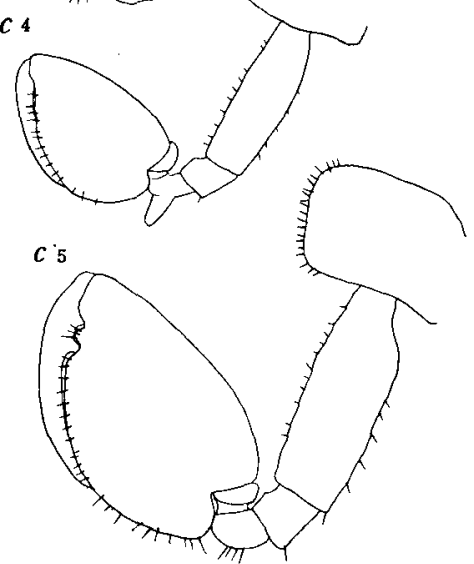<smiles>C1CCC2CCC2C1</smiles>
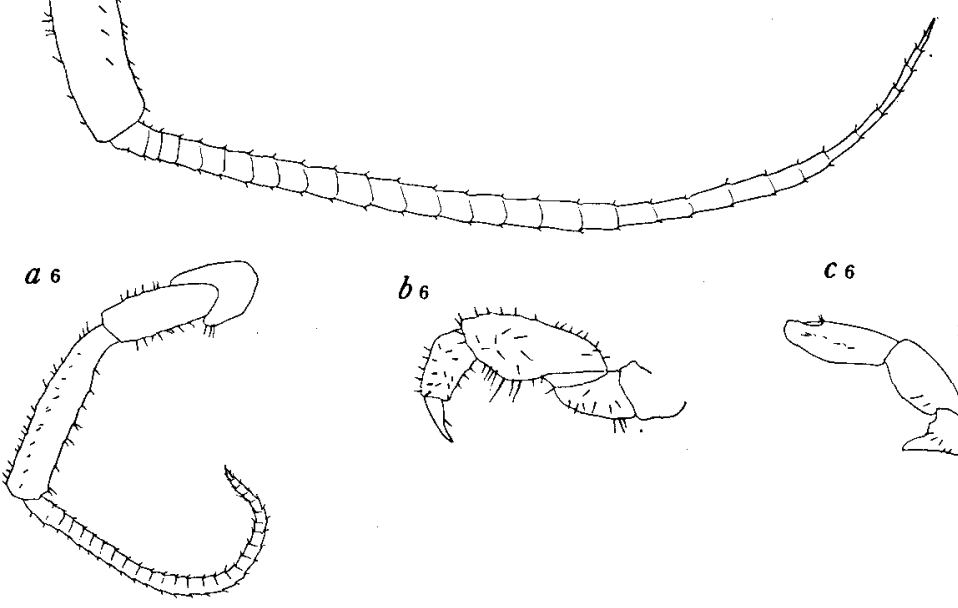

$b_{6}$

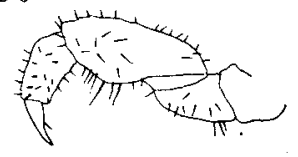

$c_{6}$

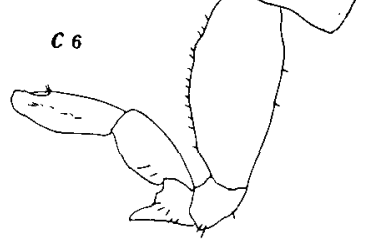

Text-fig. 11. Orchestoidea trinitatis, successive change of secondary sexual characters; $a$, antenna II $(\times 9) ; b$, gnathopod I $(\times 9)$; $c$, gnathopod II $(\times 9)$. 1, juvenile, $8.5 \mathrm{~mm} ; 2$, male, $9.3 \mathrm{~mm}$; 3 , male, $10.8 \mathrm{~mm} ; 4$, male, $14.9 \mathrm{~mm}$; male, $21.7 \mathrm{~mm}$; 6 , female, $18.9 \mathrm{~mm} ; 1,3$, 4 from Oshamanbe, 19 June, 1971; 2 from Komatsujima, 16 May, 1972; 5, 6 from Hatakejima, 16 February, 1972. 


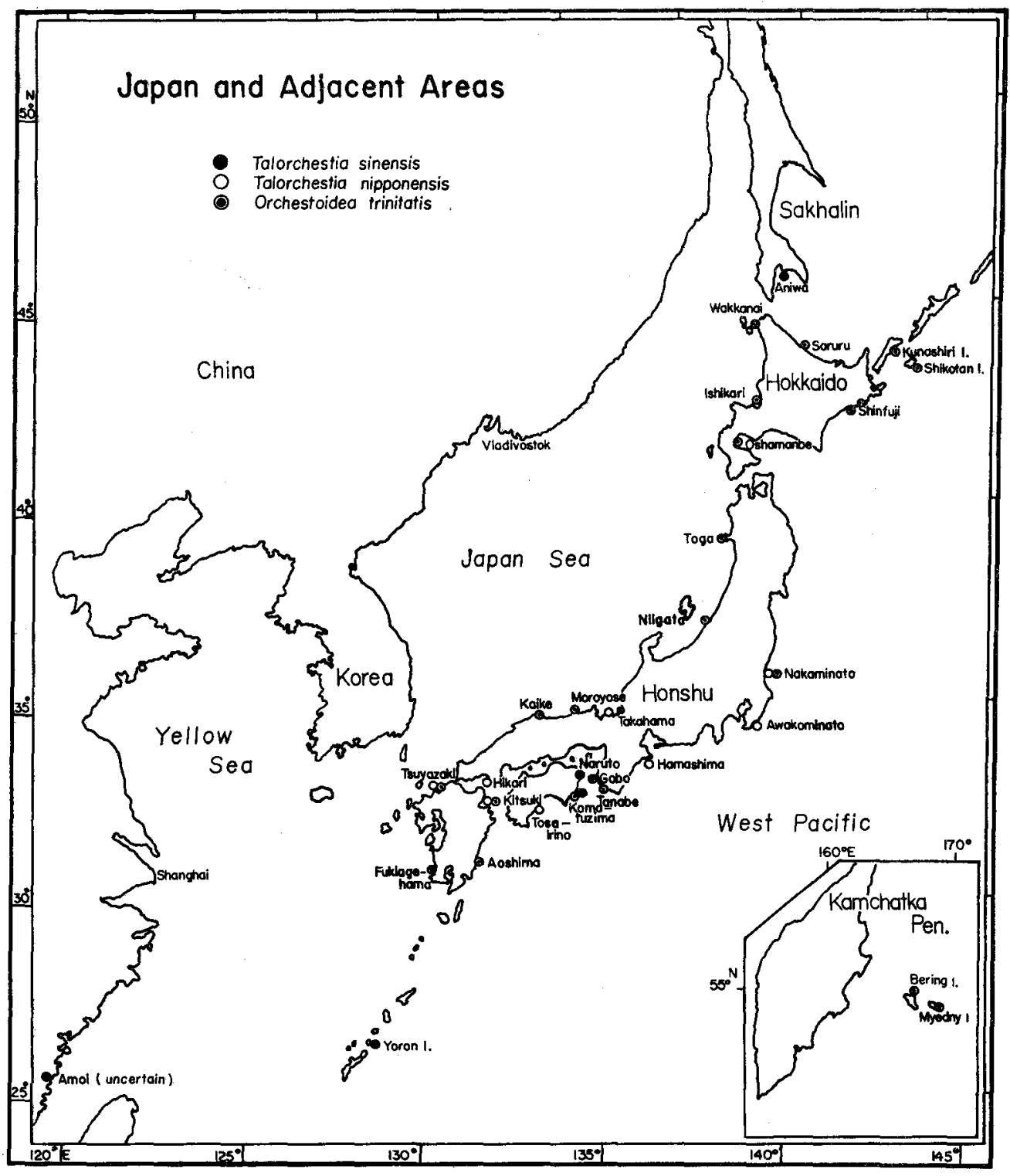

Text-fig. 12. Map showing the distributions of the three species; Talorchestia sinensis, Talorchestia nipponensis n. sp. and Orchestoidea trinitatis.

3) "pereiopod 2 (gnathopod II of female), the lower part of the 5 th joint has a notch in the proximal end"; I could not find such a feature on any specimens.

4) "pereiopod 4 (pereiopad II), the finger has some small denticles off the base of the claw," in female many specimens showed small denticles as just above, on the contrary, a few specimens showed the structure in male. Probably, all specimens 
bear such small denticles, but the position and the thickness of the article makes it difficult to be observed.

Recently, Vader (1970) after a closer comparison claimed that Talorchestia brito Stebbing and Orchestoidea trinitatis which had been synonymised by many author (Iwasa, 1939; Stephensen, 1944; Gurjanova. 1951; Bulycheva, 1957) should be kept apart as distinct species. I agree with his opinion. Generally speaking, the Pacific species Orchestoidea trinitatis, is much more spinous than the European species, Talorchestia brito, and the spines of the former are much sharper than those of the latter. In addition to the differences listed by Vader, the following can be mentioned; ramus of uropod III is much longer than peduncle in Orchestoidea trinitatis, while in Talorchestia brito the ramus is apparently shorter than peduncle as judged from the figures by Vader and Chevreux and Fage (1925). Among many differences, the presence of a small protuberance of the palm near the hinge of gnathopod II in male should be taken as the most crucial, because in the taxonomy of Talitridae, the morpholgy of gnathopod II in male has been assigned much weight.

\section{REFERENCES}

Amanieu, M. and Sulvat, B. 1963. Sur Orchestoidea fischeri (H. Milne-Edwards, 1830), Talorchestia quadrispinosa Barnard, 1916 et Talorchestia spinifera (E. Mateus, 1962), Amphipodes, Talitri- dae. Precisions systematiques et repartition geographique. Crustaceana, Vol. 8, pp. 55-65.

Barnard, J.L. 1958. Index to the families, genera, and species of the gammaridean Amphipoda (Crustacea). Allan Hancock Found. Publ., Occ. Paper, No. 19, pp. 1-146.

1969. The families and genera of marine gammaridean Amphipoda. Smithonian Inst., U. S.Nat. Mus., Bull. 271, pp. i+vi $-1+535$.

Barnard, K.H. 1951. New records and descriptions of new species of Isopods and Amphipods from South Africa. Ann. Mag. Nat. Hist., ser.12 Vol. 4, pp. 698-709.

Bousfield, E.L. 1970. Adaptive radiation in sand-burrowing amphipod Crustaceans. Chesapeake Sci., Vol. 11, No. 3, pp. 143-154.

Bulycheva, A.I. 1957. Morski blohi morej SSSR is sopredel'nykh vod (Amphipoda-Talitrodiea). Opred. po Faune SSSR, Akad, Nauk SSSR, Vol. 65, 185 pp, 66 text-figs. (in Russian)

Chevreux, E. and Fage, L. 1925. Amphipodes. Faune de France, Vol. 9, Paris. 488 pp., 438 text-figs.

Chilton, C. 1917. The New Zealand sand-hoppers belonging to the genus Talorchestia. Trans. and Proc. N. Z. Inst. Vol.49, pp. 292-303.

1925. On a species of Talorchestia. China J. Sci. and Arts, Vol. 3, pp.283-284, 1 fig.

Derzhavin, A. N. 1937. Talitridae Sovietskogo poberezh'ja Japonskogo morja. Issl. morej SSSR, Vol. 23, pp. 87-99, (in Russian) [not seen.]

Gurjanova, E. 1951. Bokoplavy morej SSSR is sporedel'nykh vod (Amphipods-Gammaridea). Opred. po Faune SSSR, Akad. Nauk SSSR, Vol. 41, 1029 pp, 705 text-figs. (in Russian)

Hurley, D.E. 1956. Studies on the New Zealand Amphipodan fauna, No. 13. Sandhoppers of the genus Talorchestia. Trans. Roy. Soc. N.Z., Vol 84, No. 2, pp. 359-389, 12 text-figs.

Iwasa, M. 1939. Japanese Talitridae. Jour. Fac. Sci. Hokkaido Imp. Uni., ser. VI, Zool., Vol. 6, No. 4, pp. 255-296, plates 9-22, text-figs. 1-27.

Klein,G. 1969. Amphipoden aus der Wesermündung und der Helgolander Bucht, mit Beschreibung von Talorchestia frisiae n. sp. Veröffentl. Inst. Meeresf. Bremerhaven. Bd xi, Ht. 2, pp. 173-194.

Reid, D.M. 1938. Burrowing methods of Talorchestia deshayesii (Audouin) (Crustacea, Amphipoda). Ann, Mag. Nat. Hist., Vol, 1, pp. 155-157. 
Ruffo,S. 1949. Studi sui crostacei Anfipodi. XIV-Su alcune specie di Anfipodi dell'Atlantico orientale. Mem. Mus. Civ. Stor. Nat. Verona, Vol. 1, pp. 123-130.

—_ 1951. Ditto. XXII-Anfipodi del Venezuela raccolti dal dott. G. Marcizzi. Ibid., Vol. 2, pp. 49-65.

Schellenberg, A. 1925. Talorchestia landanae n. sp. Beitr. Kennt. Meeresf. West Afrikas. Vol. 3, Lief. 4, pp. 113-204.

Shoemaker, C.R. 1932. Notes on Talorchestia fritzi. J. Washington Acad. Sci., Vol. 22, No. 7, pp. 184187.

Smallwood, M.E. 1903. The beach flea: Talorchestia longicornis. Cold Spring Harbor Monogr., Vol.3, pp. 3-27.

Stebbing, T.R.R. 1906. Amphipoda. I. Gammaridea, Schulze's "Das Tierreich", Lief. 21, Berlin, xxxix -806 pp., 127 text-gfis.

1921. Ispoda and Amphipoda from Angola and South Africa. Gbgs. K. Vett. Samh. Hand, Vol. 25, pp. 1-16.

Stephensen, K. 1935. Talorchestia rectimana (Dana) from Tahiti and Moorea. Bernice P. Bishop Mus. Mus. Bull. 113, pp. 143-147.

_ 1944. Some Japanese Amphipodes. Vidensk. Medd. Dansk. naturh. Foren., Vol. 108, pp. 2588.

Tattersal, W.A. 1912. Crustacea Amphipoda. Rec. Ind. Mus., Vol. 8, pp. 449-453.

Vader, W. 1970. Talorchestia brito Stebbing (Amphipoda, Talitridae): Notes on distribution, taxonomy, and biology. Sarsia, Vol. 42, pp. 83-96.

Williamson, D.I. 1951. On the mating and breeding of some semi-terrestrial Amphipods. Dove Marine Laboratory Report, 3rd ser., No. 12, pp. 49-61. 